\title{
TECHNOLOGIES OF STRATEGIC MANAGEMENT OF INDUSTRIAL ENTERPRISES
}

\author{
O.V. Loginovskiy, loginovskiyo@mail.ru, \\ A.V. Hollay, alexander@hollay.ru, \\ S.B. Rets, stanislafv.rets.84@mail.ru \\ South Ural State University, Chelyabinsk, Russian Federation
}

\begin{abstract}
The origin, formation and development of the ideas of strategic management of industrial enterprises is often based on the works of Western management scientists, who do not take into account the technological and technical aspects of the companies. This situation leads to low management efficiency of domestic enterprises in modern conditions, characterized by a high degree of instability. The actual task is to form our own management practices, taking into account the conditions in which Russian companies have to compete.

In this article, the attempt of devising a strategy of management of an industrial enterprise is made taking into account its major aspects of technical and technological development based on a developed information and computer system. The criteria to choose the options of strategic development of industrial enterprises are also presented. The positions which are necessary to consider when developing a strategy of production companies and corporations are analyzed.

The analysis made it possible to present the main provisions of the formation of a model of management of an industrial enterprise. Including the consideration of the enterprise as a materialized stream, that converts raw materials and materials into finished products of a certain range. Considering the management of the enterprise in the form of two contours: operational and strategic management, which are based on methods and technologies of system, situational, quantitative analysis. Implying the automation of management functions of the enterprise, which should be comprehensive, providing high-quality, timely and complete information with all the main stages of decision-making. Based on an integrated information system of the enterprise, the operational and main data warehouses should be interconnected.

The complex of scientific statements presented in this article forms the scientific and practical basis for the formation of management strategies for a wide variety of industrial enterprises and organizations.
\end{abstract}

Keywords: industrial enterprise, management, strategic management, strategy, instability.

\section{Introduction}

Generating, forming and developing ideas of strategic management of industrial enterprises are interpreted in different ways in scientific literature [1-10]. Nevertheless, the majority of foreign approaches, concepts [11-16] and schools of strategic management [17] don't go beyond mere managerial developments described at the verbal level while developing these or those ideas of the western management. Outside the mentioned concepts and schools there are all technological and technical aspects of performance of industrial enterprises $[18,19]$. However it is extremely difficult to ensure effective functioning of production companies and corporations without taking them into account $[20,21]$. In turn, most native authors make the views and recommendations about issues of strategic management of industrial enterprises in almost full compliance with approaches and schools of the western strategic management [22-24]. As a result, strategic management of modern industrial enterprises operating in conditions of global instability [24-28] needs a new technology focused on national conditions of business. It is necessary to add that a similar situation is considerably explained by the fact that the practice of national strategic management is still not too prominent and the regulatory base of corporate management hasn't been shaped yet [29]. As a result there is no tried and tested ideology of devising a corporate strategy as there is no analysis of long-term dynamics of their realization either. So as developments and recommendations in the field of corporate management of both foreign and native scientists are of little use to be used effectively by Russian enterprises and corporations, before using the mentioned recipes of 


\section{Краткие сообщения}

production management, the owners of companies together with top managers have to work on justification of introducing these or those actions from an arsenal of advancing a corporate strategy, yet widely used in other countries every time.

In this article the attempt of forming a strategy of management of an industrial enterprise is made taking into account its major aspects of technical and technological development on the basis of a developed information and computer system.

\section{Devising technologies of strategic management of industrial enterprises}

Contrary to a popular belief of Russian businessmen, arranging a system of strategic planning in a corporation is not a craze which came from the West but a vital necessity. The external environment changes so quickly that only operational measures on adapting the enterprise to new realities fulfilled by top management are already not enough. So as not only to survive but also to strengthen the competitive positions in the market, it is necessary to be engaged in strategic planning at a professional level. Today the need for broadening a planning horizon to coordinate short, mid and long-term goals of development, to create some kind of "a bridge" between the prospective targets of development of the enterprise and ongoing planning for a year has obviously become imminent.

In this regard, the head of any industrial enterprise should remember that irrespective of the nature of operating productions, the enterprise always endures three stages of its development [25]. At a competition stage as a rule the industrial enterprise successfully develops, increasing the volumes of the sold production in the world markets. Having reached the limit of competitiveness of its production, the industrial enterprise enters the second stage - expansion during which the enterprise compensates the reducing quality of its production compared to their competitors by the scale of its productions and sales. But the limits of expansion aren't boundless (they are outlined both by opportunities of competitors, and an extremity of the global market) and having exhausted them, the enterprise with inevitability approach the third stage of the development - remission. The enterprise begins to lose its competitive advantages. It isn't able to reduce the prime cost of its production, to carry out cardinal modernization of its productions and the concepts used by it approaches and methods of management cease to correspond to the accelerating dynamics of external influences.

We cannot but acknowledge that instability of a macroeconomic background and other influences of external environment almost for certain won't allow enterprises to realize the drawn-up strategic plans intact. However, updating strategic plans and even strategic objectives of the enterprise is an absolutely normal phenomenon allowing the enterprise to properly compensate dangerous impacts on the market position of the enterprise.

At the end of the last century foreign (followed by native) ideologists of creating a corporate strategy specified that the goal of a company consists in developing such a strategy in which the strengths of the company and weaknesses of the competitors were used and which could also be capable to neutralize the weaknesses of the company and the strengths of its rivals. The ideal was seen as competition in the healthy and growing branch with a strategy whose cornerstone is the advantage which cannot be copied or neutralized by rivals. The choice of strategic options was offered to be carried out on certain principles - the criteria of choice. They can be presented in the following groups:

- development of scenarios (scenarios are developed proceeding from strategic uncertainty and also opportunities and threats of the environment);

- need of steady competitive advantage;

- compliance with organizational vision and purposes (vision as an idea of a future state and setting tasks of the company have to encourage correct strategic decisions);

- feasibility of strategy (the enterprise has to have resources and competences as well as technical and technological basis necessary for strategy implementation).

Creating strategies of development of industrial enterprises can be carried out in various ways. Plus, in different regions of the world such strategy can even differ radically from each other.

Native industrial enterprises and corporations can carry out the following when deciding on strategic and tactical priorities:

1. Assessing administrative concepts and programs used in the company while at the same time giving preference to those which include aspects of their technical and technological development. 
2. To carry out the analysis of company structure and its personnel structure to provide not only the solution of tasks of operational management of the industrial enterprise, but also effective strategic development of the latter.

3. To improve the system of the developed production logistics at the industrial enterprise including the effective system of material support of productions, account and control of the movement of material resources on production shops of the enterprise, up to realization of finished goods and its delivery to customers.

4. To increase adequacy of the operational management system to the current tasks of the enterprise and requirements of the owners (however proved and worked through the accepted development strategy of the industrial enterprise was, it can't but be based on effective approaches, methods and models of operational management of production activity of the company).

5. To increase the quality of project management and the system of project management at the enterprise and estimate adequacy of the used production technologies of the company and need of switching to more modern industrial ways.

6. To make the analysis of information and computer infrastructure of the company and the ACS, PCS systems, etc. used at the enterprise. The most essential party of strategic development of an industrial enterprise is creating a modern information and computer infrastructure which is based on automated control systems for all fields of activity of the industrial enterprise and processes of production and economic activity which are adequate to the increased requirements of users and the level of conducting business processes.

7. To carry out the analysis of dynamics of technical and economical operating rates of the industrial enterprise or corporation.

8. To estimate the structure and quality of the used mathematical methods and models in management of an industrial enterprise. To make the structure and contents of relevant mechanisms and models of clever management. To improve the system of preparing and taking administrative decisions and the level of their validity.

The main shareholders and heads of industrial enterprises who wish to achieve high efficiency of the decisions made on business management have to encourage in every possible way so that the system of preparing and taking administrative decisions which was developed at the industrial enterprise or corporation provided the most productive realization of various tasks while achieving main objectives of the company both on the executive and strategic level.

At the same time it is necessary to remember that the process of technological renewal at industrial enterprises is cost demanding. The main shareholders and heads of industrial enterprises have to have an opportunity to reasonably estimate offers on creating projects on technological renewal of the production capacities which are available at the enterprise in the conditions of political, economic and social instability and also the increasing uncertainty in whether there will be customers of the products ready to get them of higher quality but at the increased price or on the contrary - whether it is necessary to focus on low quality of production but at lower prices, etc. In the conditions of decreased production in the world and owners' lack of considerable financial resources to switch industrial enterprises to the latest industrial technologies, it is obvious to say that in the near future a similar switch will become economically reasonable. It is quite possible that in case of lack of confidence that new technologies will certainly allow for achieving good results in the fight against competitors, it makes sense to pull time for the people in charge of making decisions on strategic imperatives of the company. And only when it becomes clear that the investments in new technologies are absolutely necessary for an industrial enterprise to survive and to secure its competitiveness, it is possible to make such expenditures.

It is worth to remember that using overseas equipment, computer facilities and software made abroad as a part of the information infrastructure of an industrial enterprise doesn't guarantee that the enterprise will be capable to carry out the production tasks and its heart - the automated information system won't glitch in case of deterioration in a military-political situation in the world.

Within the analysis of indicators of production and commercial activities of the industrial enterprise it is very important to find compliance (or discrepancy) of the developing dynamics of technical and economic indicators with other strategic imperatives of the development of the enterprise.

When devising a development strategy of the industrial enterprise or corporation it is very important to consider that in case of discrepancy of the developing dynamics to the intentions and plans of 


\section{Краткие сообщения}

the owners and heads of the industrial enterprise, the correction of the whole set of the specified strategic imperatives is necessary. It has to provide positive dynamics of indicators of technical and economic development of the company in the long run.

In this regard, the mathematical models used in different calculations have to correspond to the fact that the results received on their basis satisfy the inquiries of the people making decision at all levels of the management of the company. If any of the used models create an obstacle for solving any tasks within production chains or an administrative vertical, such model has to be replaced with more suitable or undergo substantial adjustment at the level of logical-mathematical modelling.

Depending on dynamics of change of environmental conditions and the nature of features of production activity in the company, the owners and top managers of industrial enterprises have to constantly improve the control system of all the areas and directions of production activity of the corporation, at the same time both introducing new methods and mechanisms of clever management and improving the methods and models of preparing and taking administrative decisions.

On the basis of the listed positions, the main shareholders and heads of any industrial enterprise or corporation can estimate rather objectively the strategic capacity of the company and the prospects of its further development.

Any industrial enterprise has to be constantly concerned with the fact that for the import substitution program could be successfully realized and provided production activity of the company regardless of the interests of the foreign states.

It is very important that there weren't any inefficiently working structural divisions in an industrial enterprise, company or holding.

Effective management of the development of an industrial enterprise has to be based on a modern model of management.

The modern model of management of an industrial enterprise is inconceivable without the complex automated system which includes all administrative, production, warehouse and other divisions possessing, in turn, their own (developed earlier) systems of automation (PCS, CAD, MICS, etc.).

The model of managing an industrial enterprise has to be based on the following basic provisions:

1. The enterprise is looked at from the point of view of turning the substantiated input in the form of raw materials and accompanying materials into finished goods of a certain range.

2. Business management is divided into two contours: operational and strategic management which are based on the methods and technologies of the system, situational and quantitative analysis.

3. Automation of administrative functions of the enterprise has to be complex, providing all main stages of decision-making with qualitative, timely and sufficient information.

4. At the heart of a complex information system of the enterprise there have to be operational and major databases interconnected with each other.

The architecture of the corporate information system of managing an enterprise which is aligned with the times can be presented as a set of open subsystems interacting with each other, each of which is realized in the form of a standard box or independently developed information subsystem of a certain look.

\section{Conclusion}

The complex of scientific provisions presented in this article forms a scientific and practical basis for devising a strategy of managing various industrial enterprises and organizations.

\section{References}

1. Aaker D. Strategicheskoye rynochnoye upravleniye [Strategic Market Management]. St. Petersburg, Peter, 2002. 544 p.

2. Ackoff R. Planiovanie budushchego korporatsii [Future Corporation Planning]. Moscow, 2002. $256 \mathrm{p}$.

3. Burkov V.N., Burkova I.V., Gubko M.V. Mekhanizmy upravleniya: Upravlenie organizatsiey: planirovanie, organizatsiya, stimulirovanie, kontrol': uchebnoe posobie [Management Mechanisms: Organization Management: Planning, Organizing, Motivating, Control: Tutorial]. Moscow, Lenand Publ., 2013. $216 \mathrm{p}$.

4. Knysh M.I., Puchkov VV, Tyutikov Yu.P. Strategicheskoye upravleniye korporatsiyami [Strategic Management of Corporations]. St. Petersburg, CultInform Press, 2002. 239 p. 
5. Coveney M., Ganster D., Hartlen B., King D. Strategicheskiy razryv: tekhnologii voploshcheniya korporativnoy strategii $v$ zhizn' [Strategic Gap: Technologies for Implementing Corporate Strategy in Life]. Moscow, Alpina Business Books, 2004. 232 p.

6. Koch R. Kak sozdavat' $i$ ispol'zovat' effektivnuyu strategiyu [Strategy. How to Create and Use an Effective Strategy]. St. Petersburg, Piter Publ., 2003. 320 p.

7. Mintzberg H., Alstrend B., Lempel J. Shkoly strategiy [Strategies Schools]. St. Petersburg, Piter Publ., 2000. 336 p.

8. Novikov D.A. Teoriya upravleniya organizatsionnymi sistemami [Theory of Management of Organizational Systems]. Moscow, Publishing house of physical and mathematical literature, 2012. $604 \mathrm{p}$.

9. Burkov V.N., Novikov D.A., Shchepkin A.V. Control Mechanisms for Ecological-Economic Systems. Berlin, Springer, 2015. $174 \mathrm{p}$.

10. Burkov V., Goubko M., Korgin N., Novikov D. Introduction to Theory of Control in Organizations. Boca Raton, USA, CRC Press, 2015. 346 p.

11. Brown M. Sbalansirovannaya sistema pokazateley: na marshrute vnedreniya [Balanced Scorecard: on the Implementation Route]. Moscow, Alpina Business Books, 2005. 226 p.

12. Gershun A. Tekhnologii sbalansirovannogo upravleniya [Balanced Management Technologies]. Moscow, Olympus Business, 2005. 416 p.

13. Masaaki Imai. Kaydzen: klyuch k uspekhu yaponskikh kompaniy [Kaizen: the Key to the Success of Japanese Companies]. Moscow, Alpina Business Books, 2004. 274 p.

14. Pande P. Chto takoye "Shest' sigm"? [What is Six Sigma?]. Moscow, Alpina Business Books, 2004. $158 \mathrm{p}$.

15. Raciel E.M. Metod McKinsey: Ispol'zovaniye tekhnik vedushchikh strategicheskikh konsul'tantov dlya resheniya vashikh lichnykh zadach $i$ zadach vashego biznesa [McKinsey Method: Using the Techniques of Leading Strategic Consultants to Solve Your Personal Tasks and Tasks of Your Business]. Moscow, Alpina Business Books, 2004. 194 p.

16. Scheer A-V. Modelirovaniye biznes-protsessov [Modeling of Business Processes]. Moscow, Vest'-MetaTekhnologiya, 2000. 205 p.

17. Sheldrake J. The Management Theory: From Taylorism to Japanization. St. Petersburg, Piter Publ., 2001. 352 p.

18. Anshina M. [Corporate Systems: a Revolution in Technology]. Intelligent Enterprise, 2006, no. 15 , pp. 22-27. (in Russ.)

19. Korennaya K.A., Loginovsky O.V., Maksimov A.A. [Information and Resource Management of Industrial Enterprises on the Basis of a Predictive Adaptive Approach]. Information Resources of Russia, 2012, no. 2, pp.16-20. (in Russ.)

20. Loginovsky O.V., Maksimov A.A. Korporativnoye upravleniye [Corporate Management]. Moscow, Mechanical Engineering-1, 2007, Vol. 2. 624 p.

21. Loginovsky O.V., Maksimov A.A. Korporativnoye upravleniye [Corporate Management: Scientific Edition]. Moscow, Mechanical Engineering-1, 2006, vol. 1. 603 p.

22. Kukura S.P. Teoriya korporativnogo upravleniya [Theory of Corporate Governance]. Moscow, Publishing house "Economics", 2004. 478 p.

23. Milner B.Z. Teoriya organizatsii [Theory of Organization]. Moscow, INFRA-M, 2006. 720 p.

24. Porshnev A.G., Rumyantseva Z.P., Salomatin N.A. et al. Upravleniye organizatsiyey [Organization Management]. Moscow, INFRA-M, 2005. 716 p.

25. Korennaya K.A., Loginovsky O.V., Maksimov A.A. Upravlenie promyshlennymi predpriyatiyami v usloviyakh global'nou nestabil'nosti: monografiya [Industrial Enterprises Management in Conditions of Global Instability: Monograph]. Chelyabinsk, South Ural St. Univ. Publ., 2013. 403 p.

26. Maksimov A.A., Korennaya K.A., Loginovsky O.V. [Adaptive Management of an Industrial Corporation in Conditions of Uncertainty (by the Example of Ferroalloy Production)]. Problems of Theory and Practice of Management, 2012, no. 9-10, pp.145-150.

27. Korennaya K.A., Loginovsky O.V., Maksimov A.A. Global Economic Instability and Management of Industrial Organisations. Kostanay, Kostanay State University, 2014. 227 p.

28. Loginovskiy O.V., Dranko O.I., Hollay A.V. Mathematical Models for Decision-Making on Strategic Management of Industrial Enterprise in Conditions of Instability. Workshop "International 


\title{
Краткие сообщения
}

Education in Applied Mathematics and Informatics for High Tech Applications" ("EMIT 2018”). Leipzig, Germany, 2018, vol. 2093, pp. 1-12. Available at: http://ceur-ws.org/Vol-2093/paper1.pdf.

29. Korennaya K.A., Maksimov A.A. [The Importance of the Main Production factors for a Modern Large Metallurgical Enterprise and the Development of the Theory of Corporate Governance]. Proceedings of High Schools. The Ural Region, 2011, no. 1, pp. 42-49. (in Russ.)

Received 15 June 2018

удк 658.5

DOI: $10.14529 /$ ctcr190112

\section{ТЕХНОЛОГИИ СТРАТЕГИЧЕСКОГО УПРАВЛЕНИЯ ПРОМЫШЛЕННЫМИ ПРЕДПРИЯТИЯМИ}

\author{
О.В. Логиновский, А.В. Голлай, С.Б. Рец \\ Южно-Уральский государственный университет, г. Челябинск, Россия
}

\begin{abstract}
Зарождение, формирование и развитие идей стратегического управления промышленными предприятиями чаще всего базируются на трудах западных ученых в области менеджмента, которые не учитывают технологические и технические аспекты деятельности компаний. Подобная ситуация приводит к низкой эффективности управления отечественными предприятиями в современных условиях, отличающихся большой степенью нестабильности. Актуальной является задача формирования собственных практик управления, учитывающих условия, в которых приходится конкурировать российским компаниям.

В данной статье сделана попытка формирования стратегии управления промышленным предприятием с учетом важнейших для него аспектов технического и технологического развития на базе развитой информационно-компьютерной системы. Представлены критерии выбора вариантов стратегического развития промышленных предприятий. Проанализированы позиции, которые необходимо учитывать при формировании стратегии развития производственных компаний и корпораций.

Проведенный анализ позволил изложить основные положения формирования модели управления промышленным предприятием, включающие в себя рассмотрение предприятия как овеществленного потока, преобразующего сырье и материалы в готовую продукцию определенного ассортимента; рассматривающие управление предприятием в виде двух контуров: оперативного и стратегического управления, в основе которых лежат методы и технологии системного, ситуационного, количественного анализа; подразумевающие автоматизацию управленческих функций предприятия, которая должна быть комплексной, обеспечивающей качественной, своевременной и полной информацией все основные этапы принятия решений. На основе комплексной информационной системы предприятия должны располагаться взаимосвязанные между собой оперативное и основное хранилища данных.

Комплекс научных положений, представленных в данной статье, образует научно-практическую основу для формирований стратегий управления самыми разнообразными промышленными предприятиями и организациями.
\end{abstract}

Ключевые слова: промышленное предприятие, управление, стратегическое управление, стратегия, нестабильность.

\section{Лuтература}

1. Аакер, Д. Стратегическое рыночное управление: пер. с англ. / Д. Аакер. - СПб.: Питер, 2002. $-544 c$.

2. Акофф, Р. Планирование будущего корпоращии: пер. с англ. / Р. Акофф. - М.: Сирин, 2002. $-256 c$.

3. Бурков, В.Н. Механизмы управления: Управление организацией: планирование, организа- 
ция, стимулирование, контроль: учеб. пособие / В.Н. Бурков, И.В. Буркова, М.В. Губко; под ред. Д.А. Новикова. - М.: Ленанд, 2013. - 216 с.

4. Кныш, М.И. Стратегическое управление корпорациями / М.И. Кныш, В.В. Пучков, Ю.П. Тютиков. - СПб.: КультИнформ Пресс, 2002. - 239 с.

5. Стратегический разрыв: технологии воплощения корпоративной стратегии в жизнь: пер. с англ. / М. Ковени, Д. Гэнстер, Б. Хартлен, Д. Кинг. - М.: Альпина Бизнес Букс, 2004. - 232 с.

6. Кох, Р. Стратегия. Как создавать и использовать эффективную стратегию / Р. Кох. 2-е изд. - СПб.: Питер, 2003. - 320 c.

7. Минщберг, Г. Школы стратегии / Г. Минцберг, Б. Альстренд, Дж. Лэмпел; пер. с англ. под ред. Ю.Н. Каптуревского. - СПб.: Питер. -2000. - 336 с.

8. Новиков, Д.А. Теория управления организационными системами /Д.А. Новиков. - 3-е изд. М.: Изд-во физ.-мат. лит., 2012. - 604 с.

9. Burkov, V.N. Control Mechanisms for Ecological-Economic Systems / V.N. Burkov, D.A. Novikov, A.V. Shchepkin. - Berlin: Springer, 2015. - 174 p.

10. Introduction to theory of control in organizations / V. Burkov, M. Goubko, N. Korgin, D. Novikov. - Boca Raton, USA: CRC Press, 2015. - 346 c.

11. Браун, М. Сбалансированная система показателей: на маршруте внедрения: пер. с англ. / М. Браун. - М.: Альпина Бизнес Букс, 2005. - 226 с.

12. Гершун, А. Технологии сбалансированного управления / А. Гершун, М. Горский. - М.: Олимп-Бизнес, 2005. - 416 с.

13. Масааки Имаи. Кайдзен: ключ к успеху японских компаний: пер. с англ. / М. Имаи. - М.: АльпинаБизнес Букс, 2004. - 274 c.

14. Панде, П. Что такое «Шесть сигм»? / П. Панде, Л. Холп. - М.: Альпина Бизнес Букс, 2004. $-158 c$.

15. Расиел Итан М. Метод МсКіnsеy: Использование техник ведущих стратегических консультантов для решения ваших личных задач и задач вашего бизнеса: пер. с англ. / Итан М. Расиел. - М.: Альпина Бизнес Букс, 2004. - 194 с.

16. Шеер, А-В. Моделирование бизнес-процессов / А-В. Шеер. - М.: Весть-МетаТехнология, 2000. - $205 c$.

17. Шелдрейк, Дж. Теория менеджмента: от тейлоризма до японизачии / Дж. Шелдрейк; пер. с англ. под ред. В.А. Спивака. - СПб.: Питер, 2001. - 352c.

18. Аншина, М. Корпоративные системы: револючия в технологиях / M. Аншина // Intelligent Enterprise. - 2006. - № 15. - C. 22-27.

19. Коренная, К.А. Информационно-ресурсное обеспечение управления промышленными предприятиями на основе прогнозно-адаптивного подхода / К.А. Коренная, О.В. Логиновский, А.А. Максимов // Информационные ресурсы России. - 2012. - № 2. - С. 16-20.

20. Логиновский, О.В. Корпоративное управление / О.В. Логиновский, А.А. Максимов. - М.: Машиностроение-1, 2007. - T. 2. - 624 c.

21. Логиновский, О.В. Управление промышленным предприятием / О.В. Логиновский, А.А. Максимов. - М.: Машиностроение-1, 2006. - T. 1. - 603 с.

22. Кукура, С.П. Теория корпоративного управления / С.П. Кукура. - М.: ЗАО «Издательство «Экономика», 2004. - 478 c.

23. Мильнер, Б.3. Теория организации / Б.3. Мильнер. - М.: ИНФРА-М, 2006. -720 с.

24. Управление организацией / А.Г. Поршнев, З.П. Румянцева, Н.А. Саломатин и др. - М.: ИНФРА-М, 2005. - 716 c.

25. Коренная, К.А. Управление промышленными предприятиями в условиях глобальной нестабильности: моногр. / К.А.Коренная, О.В. Логиновский, А.А. Максимов; под ред. д-ра техн. наук проф. А.Л. Шестакова. - Челябинск: Издат. иентр ЮУрГУ, 2013. - 403 с.

26. Максимов, А.А. Адаптивное управление промышленной корпораџией в условиях неопределенности (на примере ферросплавных производств) / А.А. Максимов, К.А. Коренная, О.В. Логиновский // Проблемы теории и практики управления. - 2012. - № 9-10. - С. 145-150.

27. Global Economic Instability and Management of Industrial Organisations / K.A. Korennaya, O.V. Loginovsky, A.A. Maksimov, A.V. Zimin; under editorship of D. Sc., prof. A.L. Shestakov. Kostanay State University, Kostanay, 2014. - 227 p. 


\section{Краткие сообщения}

28. Loginovskiy, O.V. Mathematical Models for Decision-Making on Strategic Management of Industrial Enterprise in Conditions of Instability / O.V. Loginovskiy, O.I. Dranko, A.V. Hollay // Workshop "International Education in Applied Mathematics and Informatics for High Tech Applications" ("EMIT 2018”). Leipzig, Germany. - 2018. - Vol. 2093. - P. 1-12. - http://ceur-ws.org/Vol-2093/paper1.pdf.

29. Максимов, А.А. Значимость основных факторов производства для современного крупного металлургического предприятия и развитие теории корпоративного управления / А.А. Максимов, К.А. Коренная // Известия вузов. Уральский регион. - 2011. - № 1. - С. 42-49.

Логиновский Олег Витальевич, д-р техн. наук, профессор, заведующий кафедрой информационно-аналитического обеспечения управления в социальных и экономических системах, Южно-Уральский государственный университет, г. Челябинск; loginovskiyo@mail.ru.

Голлай Александр Владимирович, канд. хим. наук, доцент кафедры экономики и управления на предприятиях строительства и землеустройства Высшей школы экономики и управления, Южно-Уральский государственный университет, г. Челябинск; alexander@hollay.ru.

Рец Станислав Борисович, аспирант кафедры информационно-аналитического обеспечения управления в социальных и экономических системах, Южно-Уральский государственный университет, г. Челябинск; stanislafv.rets.84@mail.ru.

Поступила в редакцию 15 июня 2018 г.

\section{ОБРАЗЕЦ ЦИТИРОВАНИЯ}

Loginovskiy, O.V. Technologies of Strategic Management of Industrial Enterprises / O.V. Loginovskiy, A.V. Hollay, S.B. Rets // Вестник ЮУрГУ. Серия «Компьютерные технологии, управление, радиоэлектроника». - 2019. - Т. 19, № 1. - С. 131-138. DOI: $10.14529 / \operatorname{ctcr} 190112$

\section{FOR CITATION}

Loginovskiy O.V., Hollay A.V., Rets S.B. Technologies of Strategic Management of Industrial Enterprises. Bulletin of the South Ural State University. Ser. Computer Technologies, Automatic Control, Radio Electronics, 2019, vol. 19, no. 1, pp. 131-138. DOI: $10.14529 /$ ctcr190112 